\title{
O NOVO TITULAR, PROFESSOR ROGÉRIO LAURIA TUCCI, PROFERE SEU DISCURSO DE POSSE
}

Excelentíssimo Senhor Professor Antonio Junqueira de Azevedo, DD. Diretor desta gloriosa Faculdade de Direito do Largo de São Francisco, em cuja pessoa, afável e amiga, permito-me saudar a Douta Congregação;

Excelentíssimo Senhor Professor e Desembargador Yussef Said Cahali, eminente Mestre e Magistrado que dignifica a nossa tradicional e sempre nova Academia e a incomparável Magistratura paulista;

Excelentíssimo Senhor Professor Carlos Alberto Bittar, igualmente ilustre Colega no magistério universitário e integrante do mesmo Poder Judiciário;

Preclaros Senhores Professores componentes da Egrégia Congregação,

Excelentíssimas Autoridades, Senhores Juízes, Procuradores e Promotores de Justiça, Advogados, Funcionários e diletos Acadêmicos,

Senhoras e Senhores,

Decorridos já cerca de trinta anos desde o primeiro concurso prestado para a Livre-Docência nesta Faculdade, concretizo hoje o perene ideal do Professor que, cultuando o magistério universitário desempenhado com o seu maior esforço e dedicação e amando seus discípulos, se renova dia a dia, como se a juventude pudesse eternizar-se: a posse como Titular, o mais elevado ponto da (a um só tempo) sacrificada e gratificante carreira.

$\mathrm{E}$ ao atingir essa tão aspirada e definitiva meta, vejo-me, de logo, contemplado com a grande satisfação e honra de ser saudado pelo eminente Professor Yussef Said Cahali, com quem convivo há décadas, experimentando, no transcorrer dos dias, cada vez maior admiração pela grandeza de sua genialidade (sempre crescente e plena de humildade, própria dos que muito sabem), e também grande afeto, agora sublimados pelas lhaneza e generosidade de suas palavras na saudação que acaba de fazer.

Agradecendo-as, com a costumeira sinceridade, valho-me, outrossim, do ensejo para externar ao igualmente preclaro e prezado Colega Carlos Alberto 
Bittar, os melhores votos da mesma exitosa atividade, até agora realizada, na sua atuação como Professor Titular da disciplina recém-criada no Departamento de Direito Civil - a de Direito de Autor, em que, como tantas outras de suas especializações, se fez Mestre consagrado.

Feito esse necessário preâmbulo, sinto-me, neste momento, no dever de sobrelevado o carinho constante de meus familiares e a diuturnamente repristinada devoção de minha esposa Tereza, companheira de todas as boas e más horas prestar imorredoira homenagem à memória do emérito Professor Joaquim Canuto Mendes de Almeida, com quem tive a felicidade de conviver, e a cujo magistério na disciplina Direito Processual Penal, nos cursos de graduação e de pós-graduação desta Faculdade, tive a honra e o privilégio de assistir, haurindo, permanentemente, lições de Direito e de vida, que contribuíram, de modo decisivo, para a minha paixão pela matéria lecionada, e para a compreensão, cada vez maior, dos desmandos e injustiças, dos arranjos de grupelhos e das proteções de paraninfados - da falácia humana, enfim -, aprendendo a perdoar, sem guardar qualquer mágoa ou rancor, todos os que não têm a mesma força de caráter dos afortunados pela Providência Divina.

Parodiando o igualmente emérito Professor Moacyr Lobo da Costa com quem, neste (ainda que em parte) autêntico sacrário de homens idealistas e independentes, também muito aprendi, especialmente no tocante ao destemor ínsito à lealdade, sinceridade e franqueza, custe o que e a quem custar -, as obras dos injustiçados remanescem, enquanto as dos seus algozes têm a duração das rosas de Malherbe: fenecem com o tempo, restando olvidadas em razão da sua inconsistência e, sobretudo, da prevalência inafastável dias mais, dias menos, da realidade, da verdade, da autenticidade.

Certo é, ainda a esse propósito, que, como expressou Luís Roberto Barroso, recente e agudamente, em conferência proferida na Faculdade de Direito da Universidade do Paraná, intitulada Direito e Paixão, "são as paixões, mais que o amor, a energia essencial que move o mundo. Há as paixões menores, como a cobiça, a vaidade, a ambição de poder. Mas há paixões redentoras, como a da liberdade e da justiça"

Estas, sim - na esteira de seu complemento é que deviam e devem nos mover "aqui na academia, no mundo universitário". vale dizer, "a paixão intelectual, a paixão do conhecimento" até porque nós "vivemos do pensamento" 
Acrescente-se que, na precisa e preciosa visão de eminentes juristas de antanho e de agora, o conhecimento requestado, mais do que pleno de erudição, deve ser temperado pela lógica e pelo bom-senso, particularmente no estudo e na maneira de interpretar as normas jurídicas, de sorte a valorá-las com o pensamento voltado ao reconhecimento e à reconstrução de seu significado, na órbita de uma ordem jurídica, como "forma representativa" do respectivo conteúdo, e feita "fonte de valoração juridica, ou que constitua objeto dessa valoração" (cf. Emilio Betti, L'interpretazione delle leggi e degli atti giuridici, Milão, Giuffrè, 1949, p. 3; em doutrinação que se difundiu, inclusive em nosso País, e. g. Fran Figueiredo, Metodologia Constitucional: Técnicas de Elaboração e Técnicas de Interpretação, Brasília, Itamari, 1987, p. 178; Nagib Salibi Filho, Anotações à Constituição de 1988: Aspectos Fundamentais, $2^{\mathrm{a}}$ ed., Rio Janeiro, Forense, 1989, p. 86).

$\mathrm{Ou}$, como intuiu, em profunda reflexão, Gustav Radbruch, Filosofia do Direito, tradução portuguesa de Cabral de Moncada, Coimbra, Armênio Amado, i 974 , p. 231, verbis:

"A interpretação juridica não é pura e
simplesmente um pensar de novo aquilo que já foi
pensado, mas, pelo contrário, um saber pensar até o fim
aquilo que já começou a ser pensado por outro. Sem
dúvida, ela parte da interpretação filológica da lei, mas
para ir mais além dela"

Foi sempre e é ainda, desse modo, que procuro conduzir as preleções, quer no curso de graduação, quer no de pós-graduação, intentando demonstrar que a norma jurídica, sem incidência sobre fato da vida, é inerme, estática; dinamizando-se, isso sim, quando este acontece.

Realmente, o Direito vive, vivifica-se constantemente, em razão dos fatos aos quais é aplicável; reclamando, por isso mesmo, do exegeta da regra de conduta humana (ao desenvolver estafante labor intelectual e volitivo, com a sensibilidade do artista, em relação à sua obra - cf., a respeito, meu Curso de Direito Processual Civil, São Paulo, Saraiva, 1989, v. 3, p. 38), a visualização do fenômeno em que se consubstancia a relação jurídica exatamente como ele é, ou seja, concretamente. 
Em suma, ficar no abstratismo das normas significa desconhecer a vida em sociedade, com todos os seus acertos e todos os seus destemperos; e que, aliás, clama, reclama, exige um permanente discernimento sobre o que nela há de ser conservado, e o que há de ser modificado, transformado.

É o que mostra, desenganadamente, Luís Roberto Barroso, na já citada conferência, relembrando o célebre episódio da Praça da Paz Celestial, em Pequim, em que destemido estudante, com o braço erguido à frente de tanque de guerra, e pleno de coragem, conseguiu paralisar, ainda que por breve tempo, a marcha das tropas chinesas; e complementando:

"É preciso, de regra, respeitar a lei e a autoridade. Mas, quando uma ou outra não forem respeitáveis, é preciso valer-se do direito de resistência, que é a paixão que se ergue, acima da lei, pela justiça e pela liberdade"

Essa a luta pelo ideal de justiça e de liberdade - de resto, é a tônica de nosso (dos meus alunos do curso de graduação, dos matriculados no curso de pós-graduação, e do cultíssimo e devotado Professor Sérgio Marcos de Moraes Pitombo, fraterno e leal amigo e colega de sempre) instrumento de trabalho, nas aulas dos semestres letivos e nossa diária atividade profissional e estudantil.

E tudo, sempre tendo em vista o sábio conselho do inolvidável Eduardo J. Couture, a saber:

"Crede no Direito como o melhor instrumento para o homem convicto; crede na Justiça como objetivo normal do Direito; crede na Paz como o substantivo piedoso da Justiça; crede na Liberdade, acima de tudo, sem a qual não há Direito, nem Justiça, nem Paz!" (in Execução da ordem de 'habeas corpus', em meu Habeas Corpus, Ação e Processo Penal, São Paulo, Saraiva, 1978, p. 51).

Muito obrigado, especialmente pelo prestigioso comparecimento, a todos os presentes! 